\title{
Tulostoma reticulatum (Agaricales, Basidiomycota), a rare stalked puffball reported from the Brazilian Atlantic rainforest
}

\author{
Lima $\mathrm{AA}^{1}$ and Baseia $\mathrm{IG}^{1,2}$
}

\author{
${ }^{1}$ Programa de Pós-Graduação em Sistemática e Evolução, Centro de Biociências, Universidade Federal do Rio \\ Grande do Norte, Av. Senador Salgado Filho, 3000, Natal, 59072-970, RN, Brazil \\ ${ }^{2}$ Departamento de Botânica e Zoologia, Centro de Biociências, Universidade Federal do Rio Grande do Norte, Av. \\ Senador Salgado Filho, 3000, Campus Universitário, Natal, 59072-970, RN, Brazil
}

Lima AA, Baseia IG 2018 - Tulostoma reticulatum (Agaricales, Basidiomycota), a rare stalked puffball reported from the Brazilian Atlantic rainforest. Studies in Fungi 3(1), 121-125, Doi $10.5943 / \mathrm{sif} / 3 / 1 / 14$

\begin{abstract}
Tulostoma reticulatum, until this report only found occurring on the Australian mainland, was found growing in sandy soil of the Brazilian Atlantic rainforest. The specimens are described and illustrated macro- and micro-morphologically, and data on taxonomy, distribution and ecology are given. This is the first record of this species outside Australia.
\end{abstract}

Key words - Biodiversity - Gasteromycetes - Neotropics - Taxonomy - Tulostomataceae

\section{Introduction}

The genus Tulostoma was proposed by Persoon (1801) and can be characterized by a twolayered peridium on a woody stipe. The spore dispersion occurs through powdery gleba puffing from the mouth by external pressure on the peridium. According to Wright (1987), this group has worldwide distribution, occurring generally in arid regions and sandy soils, although they can be found in forests, in pastures, on roads, or in alluvial areas in temperate and tropical habitats.

Tulostoma comprises around 140 species (Wright 1987), but 274 names are recorded in the Index Fungorum database (<www. indexfungorum.org >), including synonyms, forms and varieties. Currently 16 species of Tulostoma are reported in Brazil: T. beccarianum Bres., T. brasiliense J.E., T. brumale Pers., T. cretaceum Long, T. cyclophorum Lloyd, T. dumeticola Long, T. exasperatum Mont., T. excentricum Long, T. fimbriatum Fr., T. obesum Cooke \& Ellis, T. pygmaeum Lloyd, $T$. rickii Lloyd, T. rufum Lloyd, T. striatum G. Cunn., T. verrucosum Morgan and T. xerophilum Long (Cortez et al. 2009, Trierveiler-Pereira \& Baseia 2009, Trierveiler-Pereira et al. 2011).

The Mata da Pipa State Park is an important conservation area in the Atlantic rainforest, considered a global biodiversity hotspot (Myers et al. 2000). With a surface area of 290.88 hectares, it is located on the South coast of Rio Grande do Norte State, in an area of dunes, presenting the Restinga vegetation as phytophysiognomy. Other Restinga areas that have been investigated in Rio Grande do Norte State for more than a decade have revealed several species of gasteroid fungi, including new taxa for science (Baseia \& Calonge 2005, Fazolino et al. 2008, Cabral et al. 2014, Sulzbacher et al. 2016, Sousa et al. 2017). Inventories on fungi from hotspots, such as the Atlantic rainforest, are important for knowledge on fungal diversity (Hawksworth \& Lücking 2017). In this context, the present study aims to broaden knowledge about the genus Tulostoma from Brazil. 


\section{Materials \& Methods}

\section{Fieldwork and taxonomy}

Twenty specimens were collected in March 2017 at the Mata da Pipa State Park $\left(6^{\circ} 26^{\prime} 10.11^{\prime \prime S}, 35^{\circ} 05^{\prime} 31.21^{\prime \prime W}\right)$, located in Tibau do Sul, Rio Grande do Norte State, Brazil (Fig. 1).
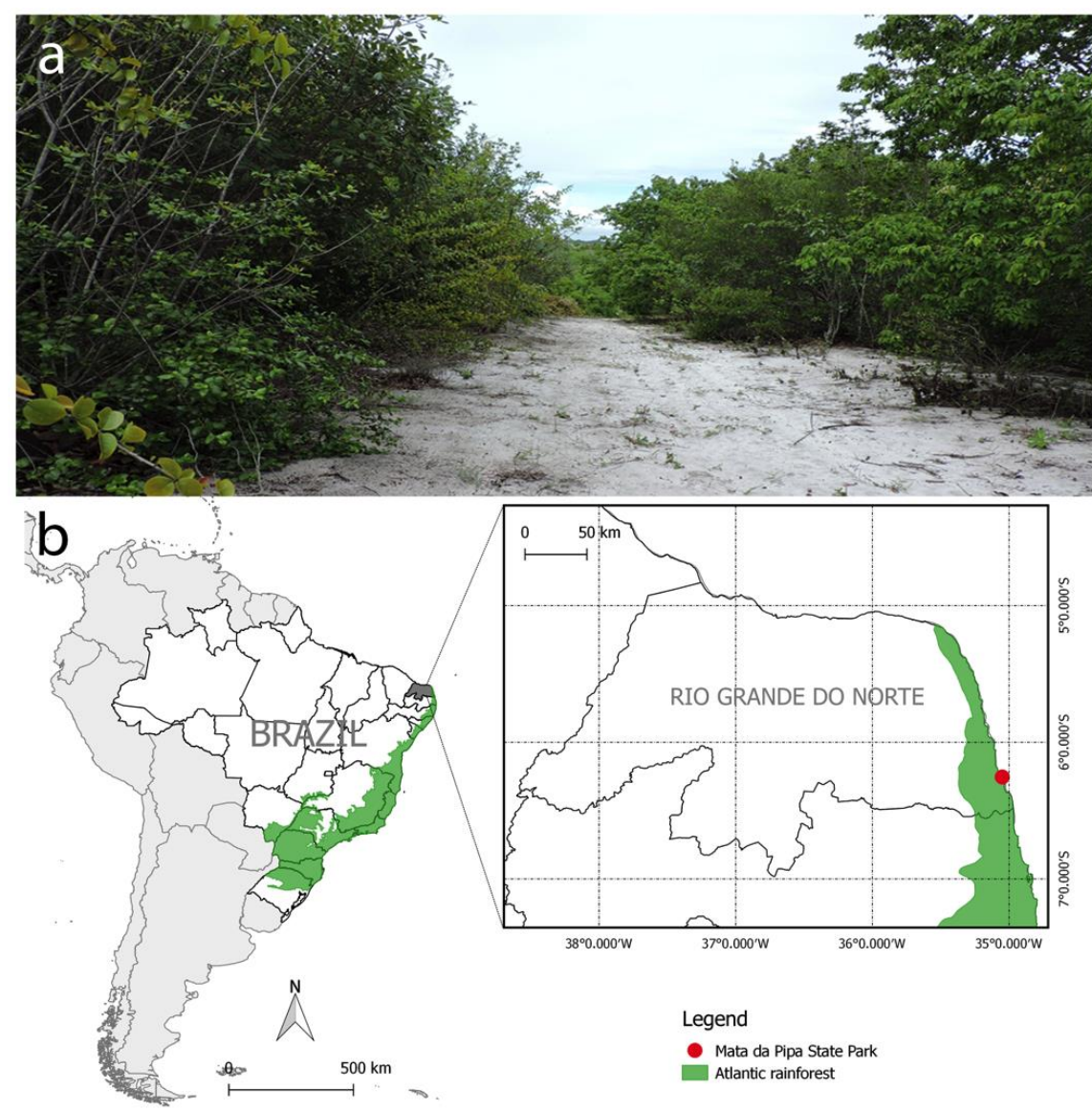

Fig. 1 - Collection site in the Atlantic rainforest area, Brazil. a Landscape images from Mata da Pipa State Park. b Map of Rio Grande do Norte State and collection site.

The specimens were collected following a methodology proposed by Baseia et al. (2014), where the basidiomata are photographed with scale, field notes are made (substrate type, geographic reference, sun exposure level, etc.), and then the specimens are removed from the substrate with the aid of a pocket knife. Morphological analysis was conducted according to Wright (1987). Macroscopic characters were performed using the Leica EZ4 stereomicroscope, the measurements were checked using a pachymeter and the colors were determined following a Küppers (2002) color guide. Microscopic characters were observed on the Nikon Eclipse NiU optical microscope (LM) with Nikon DS-Ri1 camera coupled, and measurements were taken using the Nikon NIS-Elements AR v.4.51.00 software. Slides were assembled with $5 \%$ potassium hydroxide $(\mathrm{KOH})$ and observed on $100 \times$ objective; 30 measurements were made for the basidiospores (including ornamentation), 20 measurements for capillitium and hyphae of the peridium, and the extreme values were recorded. Spore statistics $\left(\mathrm{Q}_{\mathrm{m}}\right)$ followed Bates (2004),

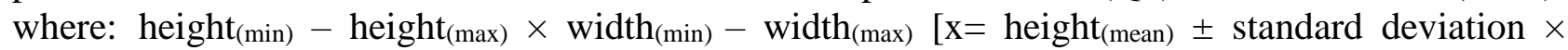
Width(mean) \pm standard deviation, $\mathrm{Q}_{\mathrm{m}}=$ mean of the quotient of basidiospores' width and length, $\mathrm{n}=$ number of randomly measured basidiospores]. Scanning electron microscopy (SEM) was performed according to Cortez et al. (2008). The specimens were deposited in the Fungi Collection of the Federal University of Rio Grande do Norte (UFRN), Natal, Brazil. 


\section{Results}

\section{Taxonomy}

Tulostoma reticulatum G. Cunn., The Gast. of Aust. and N. Zeal.: 186 (1942)

Fig. 2

Description - Immature basidiomata not observed. Spore sac subglobose to depressed globose, 6-10 mm height $\times 7-13 \mathrm{~mm}$ diam. Exoperidium formed by mixed hyphae with sand particles, brownish gray $\left(\mathrm{N}_{70} \mathrm{Y}_{70} \mathrm{M}_{40}\right)$, deciduous, persisting at the base, forming a cup-like structure. Endoperidium membranous to papery, white $\left(\mathrm{N}_{00} \mathrm{Y}_{00} \mathrm{M}_{00}\right)$, smooth, with encrusted soil particles. Mouth defined, tubular, lightly projected $(<1 \mathrm{~mm})$, not delimited, margin entire. Socket inconspicuous, slightly separated from the apex of the stipe, forming small scales. Stem 4-9 mm height $\times 1-2 \mathrm{~mm}$ diam., yellowish white $\left(\mathrm{N}_{00} \mathrm{Y}_{40} \mathrm{M}_{20}\right)$, squamulose, longitudinally striate, somewhat bulbose at the base. Gleba pulverulent, rusty orange $\left(\mathrm{N}_{30} \mathrm{Y}_{90} \mathrm{M}_{50}\right)$. Basidiospores 6.5-8.2 $\times 6.2-7.9$ $\mu \mathrm{m}\left(\mathrm{x}=7.2 \pm 0.4 \times 6.9 \pm 0.4 \mu \mathrm{m}, \mathrm{Q}_{\mathrm{m}}=1.04, \mathrm{n}=30\right)$, globose to subglobose, yellowish in $5 \% \mathrm{KOH}$, reticulate. Capillitium 2.5-4.6 $\mu \mathrm{m}$ diam., hyaline to yellowish in $5 \% \mathrm{KOH}$, thick walls $(>1 \mu \mathrm{m})$, septate and branched, breaking up at the septa, lumen present. Exoperidium hyphae 1.6-3.5 $\mu \mathrm{m}$ diam., yellowish to brownish in $5 \% \mathrm{KOH}$, thin walls $(<1 \mu \mathrm{m})$, rarely septate. Endoperidium hyphae 1.5-3.7 $\mu \mathrm{m}$ diam., hyaline, thin walls $(<1 \mu \mathrm{m})$, frequently septate, branched.

Habitat - Sandy soil.

Habit - Gregarious, in open trail exposed to sunlight.

Known distribution - Australia (Cunningham 1944), Brazil (designated here).

Material examined - Brazil, Rio Grande do Norte State, Tibau do Sul, Mata da Pipa State Park, 02 Mar 2017, 6¹6'3.45"S, 35²'32.89"W, A.A. Lima, AAL 28 (UFRN-Fungos 2903).
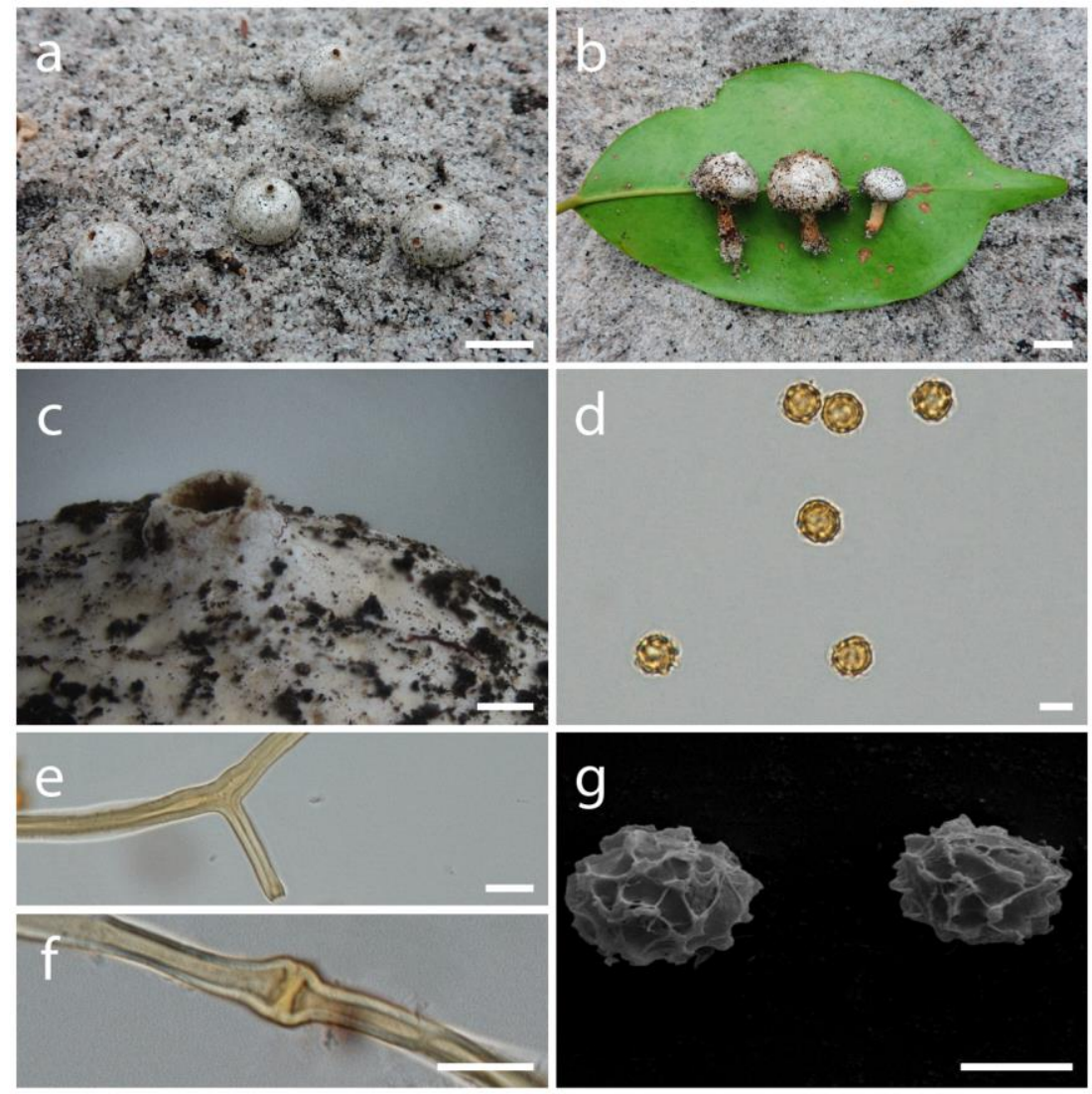

Fig. 2 - Tulostoma reticulatum (UFRN-Fungos 2903). a, b Basidiomata in situ. c Tubular mouth. d Basidiospores under LM. e, f Capillitium under LM. g Basidiospores under SEM. Scale bars: $\mathrm{a}, \mathrm{b}=10 \mathrm{~mm}, \mathrm{c}=5 \mathrm{~mm}, \mathrm{~d}, \mathrm{~g}=5 \mu \mathrm{m}, \mathrm{e}, \mathrm{f}=10 \mu \mathrm{m}$. 


\section{Discussion}

Tulostoma reticulatum is recognized by a defined and tubular mouth, hyphal exoperidium, membranous endoperidium and reticulate basidiospores. Morphological characters of the Brazilian collection are very similar to those quoted by Cunningham (1944) except the stem size, but the Australian material is bigger (up to $20 \mathrm{~mm} \times 2-4 \mathrm{~mm}$ ). In relation to the ecological aspects, the species was reported by Cunningham (1944) in sandy soil, in agreement with the observations of these authors. However, the record of the type species was made in Australia in an arid region, while in Brazil it was recorded in a tropical region.

T. exasperatosporum J.E. and T. clathrosporum J.E resemble T. reticulatum due to a defined, tubular mouth and reticulate basidiospores, but can be segregated by the membranous exoperidium (Wright 1987). Other similar species are T. exasperatum Mont., T. opacum Long and T. rickii Lloyd. However, T. exasperatum differs in its fimbriate-fibrillose mouth and verrucose to spinose exoperidium. T. opacum and $T$. rickii can be segregated by a fibrillose mouth, membranous and smooth exoperidium.

Species such as Tulostoma cyclophorum Lloyd, Tulostoma fimbriatum Fr. and Tulostoma squamosum (J.F. Gmel.) Pers. present sub-reticulate basidiospores (Esqueda et al. 2004). However, T. cyclophorum differs from T. reticulatum because it presents fibrillose mouth, and presence of mycosclereids covering the exoperidium. $T$. fimbriatum presents fimbriate mouth and $T$. squamosum presents membranous exoperidium, sometimes verrucose.

Tulostoma amnicola Long \& S. Ahmad, Tulostoma brevistipitatum B. Liu, Z.Y. Li \& Du and Tulostoma nanum (Pat.) J.E. Wright also have tubular mouth and hyphal exoperidium but can be differentiated by the basidiospore ornamentation. T. amnicola and T. brevistipitatum have smooth or almost smooth spores under SEM, while T. nanum has asperulate basidiospores (Wright 1987).

Liu (1979) described $T$. reticulatum B. Liu as a new species for China, but this name became illegitimate because it could not be considered by art. 53.1 of the International Code of Nomenclature for Algae, Fungi and Plants. Later, in his world review of Tulostoma, Wright (1987) synonymized $T$. reticulatum B. Liu with $T$. innermongolicum B. Liu. T. reticulatum and $T$. innermongolicum $(=T$. reticulatum $\mathrm{B}$. Liu) have reticulate basidiospores, hyphal exoperidium and membranous endoperidium. However, the latter presents subfibrillose mouth. According to Wright (1987), under SEM the basidiospores ornamenting this species are dispersed verrucae, small, subglobose, some anastomosed.

Jeppson et al. (2017), based on molecular data, showed that the species diversity of Tulostoma is much higher than previously known and suggested that the number of species is likely to increase even more as other areas of the world are explored. Other studies using comparative molecular analysis between type collections and morphologically similar specimens from distinct continents should be stimulated. This is the first record of T. reticulatum outside Australia.

\section{Acknowledgements}

The authors would like to express their thanks to the Coordenação de Aperfeiçoamento de Pessoal de Nível Superior (CAPES - Brazil) for the scholarships awarded to Alexandro A. Lima.

\section{References}

Baseia IG, Calonge FD. 2005 - Aseroë floriformis, a new phalloid with a sunflower shaped receptacle. Mycotaxon 92, 169-172.

Baseia IG, Silva BDB, Cruz RHSF. 2014 - Fungos Gasteroides no Semiárido do Nordeste Brasileiro. Rio Grande do Norte-Brasil: Print Mídia, 132 pp.

Bates ST. 2004 - Arizona members of the Geastraceae and Lycoperdaceae (Basidiomycota, Fungi). Master Thesis, Arizona State University, U.S.A.

Cabral TS, Silva BDB, Marinho P, Baseia IG. 2014 - Geastrum rusticum (Geastraceae, Basidiomycota), a new earthstar fungus in the Brazilian Atlantic rainforest - a molecular analysis. Nova Hedwigia 98(1-2), 265-272. 
Cortez VG, Baseia IG, Guerrero RT, Silveira RMB. 2008 - Two sequestrate cortinarioid fungi from Rio Grande do Sul, Brazil. Hoehnea 35, 513-518.

Cortez VG, Baseia IG, Silveira RMB. 2009 - Gasteroid mycobiota of Rio Grande do Sul, Brazil: Tulostomataceae. Mycotaxon 108(1), 365-384.

Cunningham GH. 1944 - Gasteromycetes of Australia and New Zealand. Dunedin, New Zealand, $236 \mathrm{pp}$.

Esqueda M, Moreno G, Perez-Silva E, Sanchez A, Altes A. 2004 - The genus Tulostoma in Sonora, México. Mycotaxon 90(2), 409-422.

Fazolino EP, Calonge FD, Baseia IG. 2008 - Geastrum entomophilum, a new earthstar with an unusuaI spore dispersal strategy. Mycotaxon 104, 449-453.

Hawksworth DL, Lücking R. 2017 - Fungal Diversity Revisited: 2.2 to 3.8 Million Species. Microbiology spectrum 5(4).

Jeppson M, Altés A, Moreno G, Nilsson RH, Loarce Y, Bustos A, Larsson E. 2017 - Unexpected high species diversity among European stalked puffballs - a contribution to the phylogeny and taxonomy of the genus Tulostoma (Agaricales). MycoKeys 21, 33-88.

Küppers H. 2002 - Atlas de los colores. 1 st ed. Barcelona: Blume, 165 pp.

Liu B. 1979 - Two new species of Tulostoma from China. Mycologia 71(6), 1275-1278.

Myers N, Mittermeier RA, Mittermeier CG, da Fonseca GA, Kent J. 2000 - Biodiversity hotspots for conservation priorities. Nature 403(6772), 853-858.

Persoon CH. 1801 - Synopsis Methodica Fungorum. Gottingae, Germany, 706 pp.

Sousa JO, Suz LM, García MA, Alfredo DS, Conrado LM, Marinho P, Ainsworth AM, Baseia IG, Martín MP. 2017 - More than one fungus in the pepper pot: Integrative taxonomy unmasks hidden species within Myriostoma coliforme (Geastraceae, Basidiomycota). PloSONE 12(6), e0177873.

Sulzbacher MA, Grebenc T, Cabral TS, Giachini AJ, Goto BT, Smith ME, Baseia IG. 2016 Restingomyces, a new sequestrate genus from the Brazilian Atlantic rainforest that is phylogenetically related to early-diverging taxa in Trappeaceae (Phallales). Mycologia 108, 954-966.

Trierveiler-Pereira L, Baseia IG. 2009 - A checklist of the Brazilian gasteroid fungi (Basidiomycota). Mycotaxon 108, 441-444.

Trierveiler-Pereira L, Gomes-Silva AC, Baseia IG. 2011 - Observations on gasteroid Agaricomycetes from the Brazilian Amazon rainforest. Mycotaxon 118(1), 273-282.

Wright JE. 1987 - The genus Tulostoma (Gasteromycetes) - A world monograph. J. Cramer, Berlin, Stuttgart. 